\title{
風の乱れにおよぼす小地形の影響
}

\section{立石由 已*}

\section{I 序}

風がきわめて局地的に変化していることは古くか ら知られており，小地域における風に関しての研究 は，微気象学，微気候学の立場から多くなされてい る. 模式的な地形の場合として，平面に直線的な谷 がきざまれている場合の平均風速，平均風向，風速
変動量などと地形との関係についての報告がなされ ている122).また広い平垣な地面における風速垂直 分布が小地形の影響によって变化している状態が報 告されている ${ }^{3)}$. 乱流交換係数についても, 温水池 上文や耕地上 ${ }^{5)}$ で行われている.

今回の報告は風の乱れの強さや乱流交換係数が, 小地形の影響によって変化している状態について調

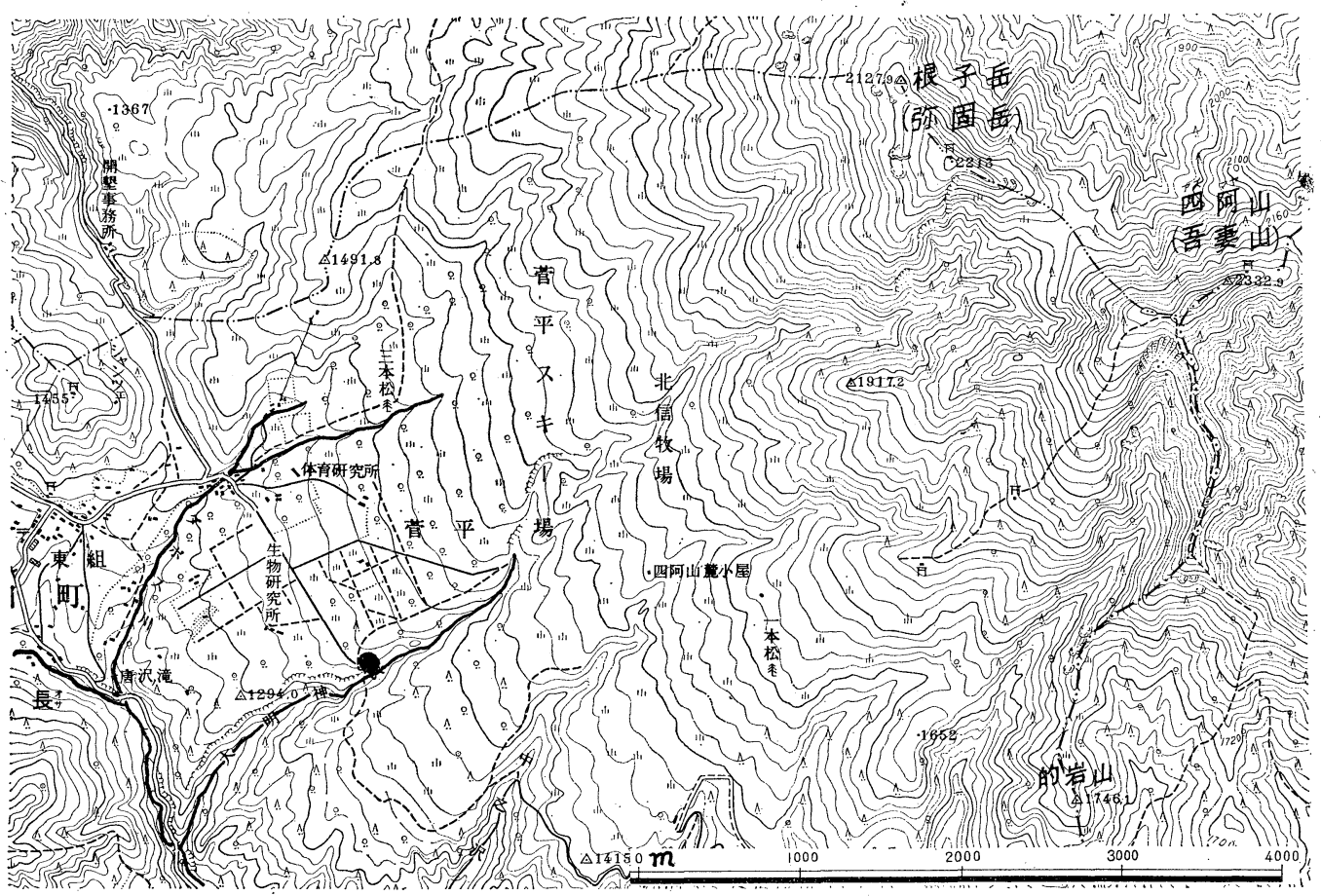

第 1 図観測地点（○）とその附近の概念図

* 水温調查会

1) Yoshino, M. (1957) : The structur of surface winds crossing a small valley. Jour. Met. Soc. Japan, 35, 184-195.

2) Yoshino, M. (1958) : Wind speed profiles of the lowest air layer under influences of micro-topography. Jour. Met. Soc. Japan, 36, 174-186.

3）吉野正敏（1958）：接地層の風の垂直分布と小地形. 東教大地理研報告 II 119-146.

4）内島善兵衛（1959）：温水池上に打ける運動量, 熱量, 水蒸気量の乱流輸送. 農技研報告 $\mathrm{A}, 7,69-96$.

5）谷 信輝 (1963）：耕地風に関する研究. 農技研報告 A，10，1-99. 
ベたものである.

\section{II 観 測 方 法}

観測を行ったのは長野県小県郡真田町菅平の四阿 山と根子岳の鞍部に源を発している大明神沢の南向 き斜面である(第 1 図). 谷の上限の幅は $170 \sim 180 \mathrm{~m}$, 谷底の幅は $30 \sim 40 \mathrm{~m}$, 谷の側壁斜面の傾斜 $28^{\circ}$, 斜 面は凹凸が少なく，地表面は草丈 $30 \mathrm{~cm}$ 位のクマザ サ，シバ，ワラビで掩われていた． 観測斜面の断面 は第 2 図に示す通りである.

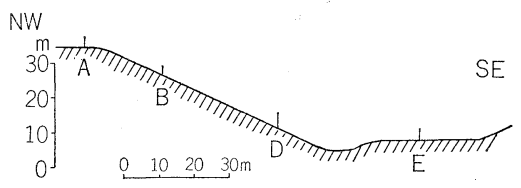

第 2 図観測斜面断面図

観測は 1958 年 8 月 5 日〜 8 日の 4 日間行った. 使用した測器は理工研式小型ロビンソン風速計 2 組 と通風式小型サーミスター温度計 2 組である. 1 組 は谷からはなれた平原上の地点 $\mathrm{A} に$ 固定し，他の 1 組は谷の中の地点を移動させて観測した.すなわち, 谷の外 (地点 $\mathrm{A}$ ) と中 (地点 $\mathrm{B}$, 地点 $\mathrm{D}$, 地点 $\mathrm{E}$ ) との地点において同時観測をつぎつぎと行った。し たがって，谷の中の 2 地点相互の観測時刻はずれて いる. 観測高度は地上 $0.5 \mathrm{~m}$ および $2.0 \mathrm{~m} \mathrm{の} 2$ 点で, 地点 $\mathrm{A}$ では地上 $1 \mathrm{~m}$ の風向を中浅式風向風速計で同 時に観測した．観測は 30 秒ごとに 10 分間読み取り を 1 回として, 延 37 回行った.

\section{III 結果と考察}

\section{a ）乱れの強さ}

乱れの強さ $g$ は 30 秒ごとに 10 分間行った風速変 動量の標準偏差 $\sqrt{\overline{u^{\prime 2}}}$ を 10 分間の平均風速 $\bar{u}$ で割 ったもので, 次式で示される.

$$
g=\sqrt{\overline{u^{\prime 2}}} / \bar{u} \text {....... }
$$

各地点における観測結果は第 1 表に示したとおり である. 全回数を通じての結果では，平原上の地点 $\mathrm{A}$ で 0.35 , 地点 $\mathrm{B}$ で 0.47 , 地点 $\mathrm{D}$ で 0.71 , 谷底の 地点 $\mathrm{E}$ で 9.79 , と斜面を下るにつれて大きくなって いる.これは風速が尾根から谷底に向って弱くなっ ているためであろう.

つぎに谷の外の風の状態と, 谷間の気温分布の状 態との関係をみるために，地点 $\mathrm{A} の$ 乱れの強さと，
第 1 表 乱れの強さ $g$ の観測值と気温差 および風向

\begin{tabular}{|c|c|c|c|c|c|}
\hline 日 & 時 & $\begin{array}{l}\text { 地点A } \\
\text { の } g\end{array}$ & 地点 B & $\theta_{A}-\theta_{B}$ & 風 向 \\
\hline \multirow[t]{4}{*}{$8 / 5$} & $\underset{14.50-15.00}{\mathrm{~h}}$ & 0.276 & 0.520 & -0.6 & $\mathrm{~N}$ \\
\hline & $15.00^{-} \quad .10$ & 0.223 & 0.402 & -0.3 & NW \\
\hline & $15.15^{-} \quad .25$ & 0.134 & 0.405 & -0.4 & NW \\
\hline & $15.30-\quad .40$ & 0.165 & 0.462 & -0.2 & NW \\
\hline \multirow[t]{4}{*}{$8 / 6$} & $14.30^{-} \quad .40$ & 0.458 & 0.470 & 0.7 & SW \\
\hline & $14.45^{-} \quad .55$ & 0.344 & 0.302 & 0.8 & S W \\
\hline & $15.00-\quad .10$ & 0.472 & 0.605 & 0.4 & S W \\
\hline & $15.15^{-} \quad .25$ & 0.403 & 0.634 & 0.1 & NW \\
\hline \multirow[t]{3}{*}{$8 / 8$} & $16.00^{-} \quad .10$ & 0.314 & 0.271 & -0.5 & $\mathrm{SE}$ \\
\hline & $16.15^{-} \quad .25$ & 0.491 & 0.576 & -0.2 & $\mathrm{~S}$ \\
\hline & $16.30^{-} \quad .40$ & 0.251 & 0.516 & -0.3 & NW \\
\hline 平 & 均 & 0.321 & 0.469 & & \\
\hline
\end{tabular}

\begin{tabular}{|c|c|c|c|c|c|}
\hline 日 & 時 & $\begin{array}{l}\text { 地点A } \\
\text { の } g\end{array}$ & $\begin{array}{l}\text { 地点 } \mathrm{D} \\
\text { の } g\end{array}$ & $\theta_{A}-\theta_{D}$ & 風 向 \\
\hline \multirow[t]{2}{*}{$8 / 6$} & $\begin{array}{cc}\mathrm{h} \mathrm{m} & \mathrm{m} \\
17.05^{-} & .15\end{array}$ & 0.350 & 0.923 & & NW \\
\hline & $17.20^{-} \quad .30$ & 0.198 & 0.307 & & NW \\
\hline \multirow[t]{7}{*}{$8 / 7$} & $10.51-11.01$ & 0.264 & 0.577 & 0.9 & $\mathrm{~S}$ \\
\hline & $11.05^{-} \quad .15$ & 0.439 & 0.565 & 0.8 & S W \\
\hline & $11.40^{-} \quad .50$ & 0.478 & 0.705 & 0.6 & W \\
\hline & $11.55-12.05$ & 0.515 & 0.873 & 0.8 & W \\
\hline & $14.15^{-} \quad .30$ & 0.307 & 0.645 & 0.4 & S W \\
\hline & $14.45^{-} \quad .55$ & 0.508 & 0.618 & 0.6 & W \\
\hline & $15.00^{-} .10$ & 0.342 & 0.552 & 0.1 & $\mathrm{~S}$ \\
\hline \multirow[t]{3}{*}{$8 / 8$} & $14.40^{-} \quad .50$ & 0.283 & 0.860 & 0.1 & S E \\
\hline & $14.55-15.05$ & 0.294 & 0.884 & -0.1 & $\mathrm{E}$ \\
\hline & $15.25-.35$ & 0.297 & 0.957 & -0.3 & $\mathrm{~S}$ \\
\hline & 均 & 0.356 & 0.706 & & \\
\hline
\end{tabular}

\begin{tabular}{|c|c|c|c|c|c|}
\hline 日 & 時 & $\begin{array}{l}\text { 地点 } \mathrm{A} \\
\text { の } g\end{array}$ & $\begin{array}{l}\text { 地点 } \mathrm{E} \\
\text { の } g\end{array}$ & $\theta_{A}-\theta_{E}$ & 風 向 \\
\hline \multirow[t]{4}{*}{$8 / 7$} & $\begin{array}{cc}\mathrm{h} \mathrm{m} & \mathrm{m} \\
16.10^{-} & .20\end{array}$ & 0.304 & 0.678 & 0.0 & SW \\
\hline & $16.25^{-} .35$ & 0.458 & 0.678 & 0.0 & NW \\
\hline & $16.40^{-} \quad .55$ & 0.458 & 0.754 & 0.1 & $\mathrm{~N}$ \\
\hline & $16.55-17.05$ & 0.249 & 0.676 & 0.2 & W \\
\hline \multirow[t]{10}{*}{$8 / 8$} & $10.39-\quad .49$ & 0.412 & 0.579 & 1.1 & $\mathrm{SE}$ \\
\hline & $10.55-11.05$ & 0.344 & 0.715 & 0.9 & $\mathrm{~S}$ \\
\hline & $11.10-\quad .20$ & 0.386 & 0.732 & 0.4 & $\mathrm{~S}$ \\
\hline & $11.25-.35$ & 0.352 & 0.805 & 0.1 & $\mathrm{~S}$ \\
\hline & $11.40-\quad .50$ & 0.286 & 0.743 & 0.0 & $\mathrm{~S}$ \\
\hline & $11.55-12.05$ & 0.362 & 0.924 & 0.7 & SW \\
\hline & $13.15^{-} .25$ & 0.354 & 0.558 & 0.2 & $\mathrm{~S}$ \\
\hline & $13.30^{-} \quad .40$ & 0.345 & 0.735 & . -0.2 & $\mathrm{~S}$ \\
\hline & $13.44^{-} \cdot .55$ & 0.342 & 1. 162 & -0.3 & $\mathrm{SE}$ \\
\hline & $14.00-\quad .10$ & 0.417 & 1.273 & -0.5 & $\mathrm{~S}$ \\
\hline$T$ & 均 & 0.362 & 0.787 & & \\
\hline
\end{tabular}




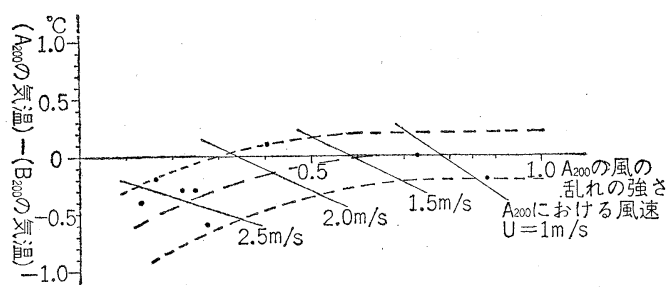

第3図 $\mathrm{A}_{200}$ において北寄りの風における 風の乱れの強さと $\left(\mathrm{A}_{200}\right.$ の気温 $)$ $\left(\mathrm{B}_{200}\right.$ の気温) との関係

地点 $\mathrm{A}$ と各地点のそれぞれ地上 $2 \mathrm{~m}$ の気温差との間

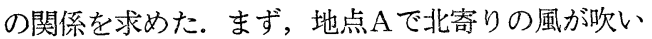

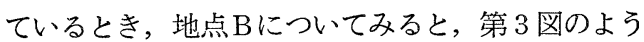
になる. 気温差が負ということは, 地点 $\mathrm{A}$ の気温が 地点Bより低いことを意味している. したがって, 地点 $\mathrm{A}$ において風が強くなると, すなわち平均風速 uが大となると， $\mathrm{A}_{200}$ の風の乱れの強さは小さくな

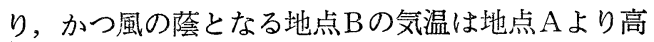
くなる．地点 $\mathrm{A} の$ 風速が $1 \mathrm{~m} / \mathrm{s}$ 位になると， $\mathrm{A}, \mathrm{B}$ 両地点の気温はほぼ等しくなる。

地点Dについてみると第 4 図のような関係が認め られる.すなわち地点Aの乱れの強さが大きくなる と，地点 $\mathrm{D}$ の気温は地点 $\mathrm{A} よ り$ 低くなる.このこと は, 地点Aに打ける風速が弱くなると, 谷の中に形 成される地形による渦が上昇してきて, 一般風の影 響が谷の中では小さくなり，風が強いときは一般風 の影響が谷の中にまで強くおよび，地点 $\mathrm{A}$ と地点 $\mathrm{D}$ との気温差が小さくなるためであろう。この状態を 模式的に画いてみると第 5 四(a)，(b)のようになる.

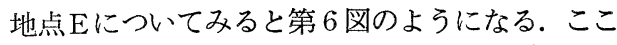

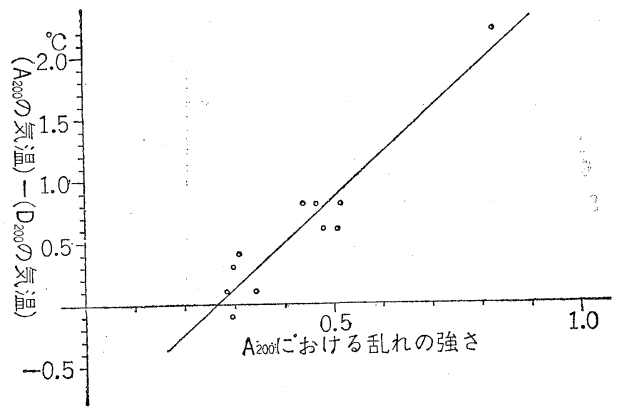

第 4 図” $\mathrm{A}_{200}$ における風の乱れの強さと $\left(\mathrm{A}_{200}\right.$ の気温 $)-\left(\mathrm{D}_{200}\right.$ の気温 $)$ の 関係 (a)

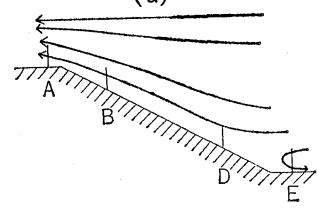

(b)
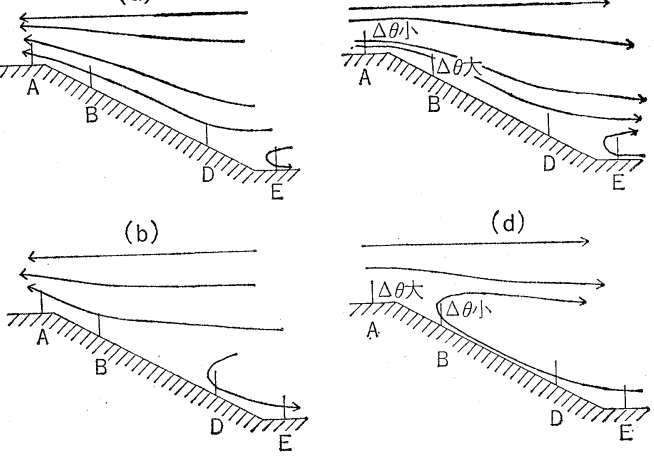

(d)

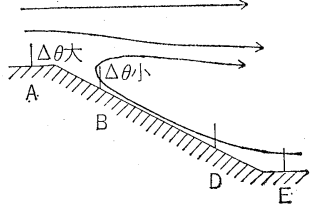

第5図谷を横切る風とそれによって生 じる渦の模式図

地点 $\mathrm{A}$ と地点 $\mathrm{B}$, 地点 $\mathrm{D}$, 地点 $\mathrm{E}$ の関係を示す.

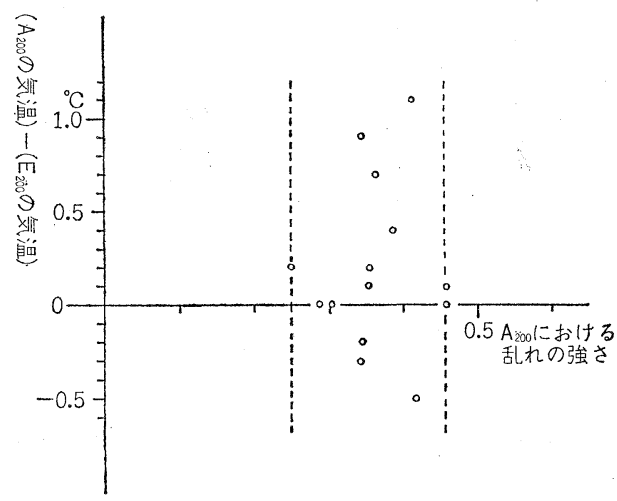

第 6 図 $\mathrm{A}_{200}$ における風の乱れの強さと $\left(\mathrm{A}_{200}\right.$ の気温 $)-\left(\mathrm{E}_{200}\right.$ の気温 $)$ の関 係

では地点Aの乱れの強さとは無関係に 2 地点の気温 差が変化している.すなわち，この程度の谷におい ては，谷底では一般風とは無関係に風が吹いている ことを示している.

b) 乱流交換係数

各地点についての乱流交換係数 $K$ は次式で求め $た^{6)}$.

$$
K=\frac{1.14 \Delta u}{\ln \frac{z_{2}}{z_{1}}}\left[1+\frac{\Delta \theta}{(\Delta u)^{2}} \ln \frac{z_{2}}{z_{1}}\right] \cdots \cdots(2)
$$

ただし， $z_{2}, z_{1}$ は観測高度， $\Delta u, \Delta \theta$ は高度 $z_{1}$ と $z_{2}$ との間の風速差，および気温差である． $z_{2}$ を $2 \mathrm{~m}$ $z_{1}$ を $0.5 \mathrm{~m}$ にとると $K$ は高度 $1 \mathrm{~m}$ の乱流交換係数 を示す。観測結果は第 2 表に示す.

6）エム・イ・ブドウィコ（1959）：地表面の熱収支（内島善兵衛訳）。河川水温調査会. 
第 2 表 乱流交換係数 $K\left(\mathrm{~m}^{2} / \mathrm{s}\right)$, 気温の 高度差 $\Delta \theta\left({ }^{\circ} \mathrm{C}\right)$ および風速 $u(\mathrm{~m} / \mathrm{s})$

\begin{tabular}{|c|c|c|c|c|c|c|c|c|}
\hline \multirow{2}{*}{ E } & & \multicolumn{3}{|c|}{ 地 点 $\mathrm{A}$} & \multicolumn{3}{|c|}{ 地 点 $B$} \\
\hline & & & $K$ & $\Delta \theta$ & $u$ & $K$ & $\Delta \theta$ & $u$ \\
\hline \multirow[t]{4}{*}{$8 / 5$} & $\begin{array}{c}\mathrm{h} \mathrm{m} \\
14.50-1\end{array}$ & $\begin{array}{r}\mathrm{m} \\
5.00\end{array}$ & 0.3394 & 1.6 & 2.9 & 0.4508 & 1.9 & 1.8 \\
\hline & $15.00^{-}$ & .10 & 0.3243 & 1.5 & 2.6 & 0.5274 & 2.0 & 1.5 \\
\hline & $15.15^{-}$ & .25 & 0.3088 & 1.6 & 2.6 & 0.5547 & 1.8 & 1.5 \\
\hline & $15.30^{-}$ & .40 & 0.3088 & 1.4 & 2.7 & 0.5508 & 2.1 & 1.3 \\
\hline \multirow[t]{4}{*}{$8 / 6$} & $14.30^{-}$ & .40 & 0.1107 & 0.2 & 1.2 & 欠 & & 則 \\
\hline & $14.45^{-}$ & .55 & 0.5547 & 1.8 & 1.8 & 0.4791 & 2.7 & 1.6 \\
\hline & $15.00^{-}$ & .10 & 0.5508 & 2.1 & 1.3 & 0.3811 & 2.0 & 1.8 \\
\hline & $15.15^{-}$ & .25 & 0.4574 & 1.7 & 1.6 & 0.4134 & 1.9 & 1.5 \\
\hline \multirow[t]{3}{*}{$8 / 8$} & $16.00^{-}$ & .10 & 0.4108 & 1.7 & 1.5 & 0.2308 & 0.8 & 1.4 \\
\hline & $16.15^{-}$ & .25 & 0.2831 & 1.3 & 2.8 & 0.1990 & 0.7 & 2.8 \\
\hline & $16.30^{-}$ & .40 & 0.2708 & 1.0 & 1.8 & 0.1065 & 0.2 & 1.6 \\
\hline
\end{tabular}

\begin{tabular}{|c|c|c|c|c|c|c|c|}
\hline \multirow{2}{*}{ E } & \multirow[t]{2}{*}{ 吽 } & \multicolumn{3}{|c|}{ 地 点 $\mathrm{A}$} & \multicolumn{3}{|c|}{ 地 点 $\mathrm{D}$} \\
\hline & & $K$ & $\Delta \theta$ & $u$ & $K$ & $\Delta \theta$ & $u$ \\
\hline \multirow[t]{7}{*}{$8 / 7$} & $\underset{10.51-11.01}{\mathrm{~h} m}$ & 0.4488 & 2.3 & 2.0 & 0.5547 & 1.8 & 1.3 \\
\hline & $11.05^{-} .15$ & 0.2932 & 1.3 & 1.6 & 0.2729 & 1.3 & 1.4 \\
\hline & $11.40-.50$ & 0.2240 & 0.7 & 1.2 & 0.2384 & 0.9 & 0.7 \\
\hline & $11.55-12.05$ & 0.1707 & 0.5 & 1.2 & 0.1704 & 0.6 & 0.7 \\
\hline & $14.15-.30$ & 0.2308 & 0.8 & 1.3 & 0.3174 & 1.1 & 0.7 \\
\hline & $14.45^{-} \quad .55$ & 0.2908 & 1.1 & 1.8 & 0.2473 & 0.8 & 1.1 \\
\hline & $15.00-.10$ & 0.8075 & 3.2 & 1.9 & 0.5710 & 2.4 & 1.4 \\
\hline \multirow[t]{3}{*}{$8 / 8$} & $14.40^{-} \quad .50$ & 0.1796 & 0.5 & 1.3 & 0.2140 & 0.6 & 1.7 \\
\hline & $14.55-15.05$ & 0.2262 & 0.9 & 1.3 & 0.2107 & 0.7 & 0.0 \\
\hline & $15.25^{-} .35$ & 0.5267 & 1.7 & 1.5 & 0.4508 & 1.9 & 0.7 \\
\hline
\end{tabular}

\begin{tabular}{|c|c|c|c|c|c|c|c|}
\hline \multirow{2}{*}{ 日 } & \multirow{2}{*}{ 時 } & \multicolumn{3}{|c|}{ 地 点 $\mathrm{A}$} & \multicolumn{3}{|c|}{ 地 点 $E$} \\
\hline & & $K$ & $\Delta \theta$ & $u$ & $K$ & $\Delta \theta$ & $u$ \\
\hline \multirow[t]{4}{*}{$8 / 7$} & $\begin{array}{cc}\mathrm{h} \mathrm{m} & \mathrm{m} \\
16.10^{-} & .20\end{array}$ & 0.2940 & 1.0 & 1.6 & 0.2303 & 0.3 & 1. \\
\hline & $16.25^{-} \quad .35$ & 0.2033 & 0.7 & 1.8 & & 1.0 & 1.5 \\
\hline & $16.40-\quad .55$ & 0.1531 & 0.4 & 2.4 & & 0 & 1. \\
\hline & $16.55-17.05$ & 0.1376 & 0.3 & 2.7 & -0.0606 & 0 & 1. \\
\hline \multirow[t]{9}{*}{$8 / 8$} & $10.39-\quad .49$ & 0.5108 & 2.2 & 2.1 & 0.4038 & 0.8 & 1.1 \\
\hline & $10.55-11.05$ & 0.7635 & 3.9 & 2.3 & 0.4038 & 0.8 & 1. \\
\hline & $11.10^{-} .20$ & 0.6511 & 3.6 & 2.5 & & 1.5 & 1.3 \\
\hline & $11.25^{-} .35$ & 0.6044 & 3.3 & 2.7 & & & \\
\hline & $11.40-\quad .50$ & 1.1149 & 3.8 & 2.3 & 0.7905 & 1.1 & 0.7 \\
\hline & $11.55-12.05$ & 0.3811 & 2.0 & 2.5 & 0.5104 & 0.7 & 1. \\
\hline & $13.15^{-} .25$ & 0.2691 & 1.2 & 2.7 & 0.0902 & 0.1 & 1.2 \\
\hline & $14.44-\quad .55$ & 0.2270 & 0.9 & 2.4 & -0.0303 & 0.0 & 0.5 \\
\hline & $14.00^{-} .10$ & 0.2734 & 1.1 & 1.9 & & -0.2 & 0.5 \\
\hline
\end{tabular}

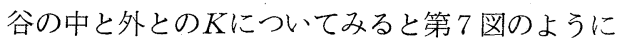
なる．観測点が風の蔭になる北寄りの風の場合は第 7 図の実線で示される.すなわち, 地点 $\mathrm{A}$ と地点 $\mathrm{B}$

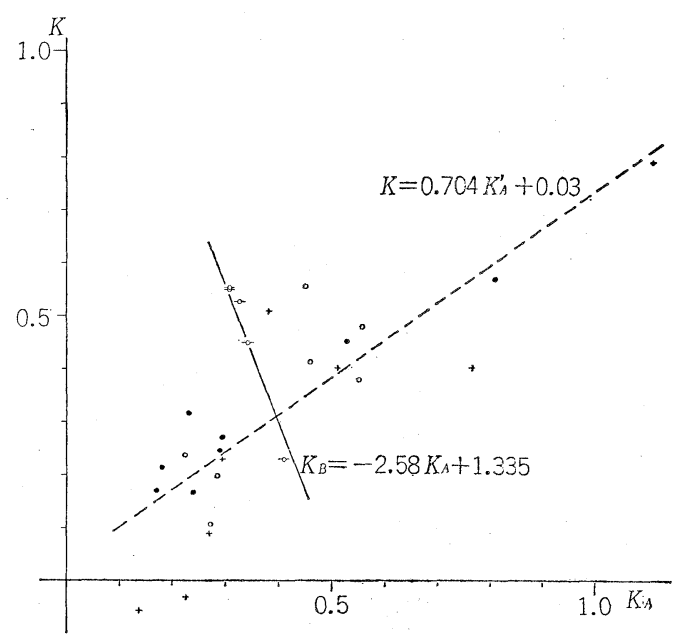

第 7 図.地点 $\mathrm{A}$ の乱流交換係数と地点 $\mathrm{B}$, 地点 $\mathrm{D}$, 地点 $\mathrm{E} の$ 乱流交換係数の 関係

- 地点 $\mathrm{A}$ で北寄りの風のときの地点 $\mathrm{B}$ の値

$\bigcirc$ 地点 $\mathrm{A}$ で南寄りの風のときの地点 $\mathrm{B}$ の值

- " 地点 $\mathrm{D}$ の值 地点 $\mathrm{E}$ の値

との場合しか観測されていないが，次式で示される.

$$
K_{B}=-2.58 K_{A}+1.335 \quad \mathrm{r}=0.882^{7) \cdots \cdots .(3)}
$$

ただし， $K_{B}, K_{A}$ はそれぞれ地点 $\mathrm{B}$ および地点 $\mathrm{A}$ の乱流交換係数. これからわかるように $K_{A}$ が大き くなるとともに $K_{B}$ が小さくなっていく．これを解 釈すると第 5 図の $(\mathrm{C})$ に示すように風が強くなると 地点 $\mathrm{A}$ で $\Delta \theta$ が小さくなり，一方地点 $\mathrm{B}$ では $\Delta \theta$ が 比較的大きい。また第 5 図(D)に示すように風が弱 まると $\Delta \theta$ が地点 $\mathrm{A}$ で大, 地点 $\mathrm{B}$ では地形によって 形成された渦のため $\Delta \theta$ は小さくなるためである.

南寄りの風の場合は第 7 図の破線で示され, 次式 のようになる。

$$
K=0.704 K^{\prime}{ }_{A}+0.030 \quad \mathrm{r}=0.838 \cdots \cdots(4)
$$

$K$ は地点 $\mathrm{B}$, 地点 $\mathrm{D}$, 地点 $\mathrm{E}$ の乱流交換係数を区 別なしに用いたもの, $K^{\prime}{ }_{A}$ は地点 $\mathrm{A}$ で南寄りの風の 時の乱流交換係数である.すなわち，斜面が卓越風 に面しているときは, 谷の中も外と比例してKが変 化する. すなわち, 谷の中の地点における $K$ は $K^{\prime}{ }_{A}$ の約 0.7 倍の值をとることがわかった.

次に $0.5 \mathrm{~m}$ と $2 \mathrm{~m}$ の高度の気温差 $\Delta \theta$ と $K$ との間 の相関についてみると第 8 図のようになる.

7）相関係数 危険率 0.05 で有意である. 


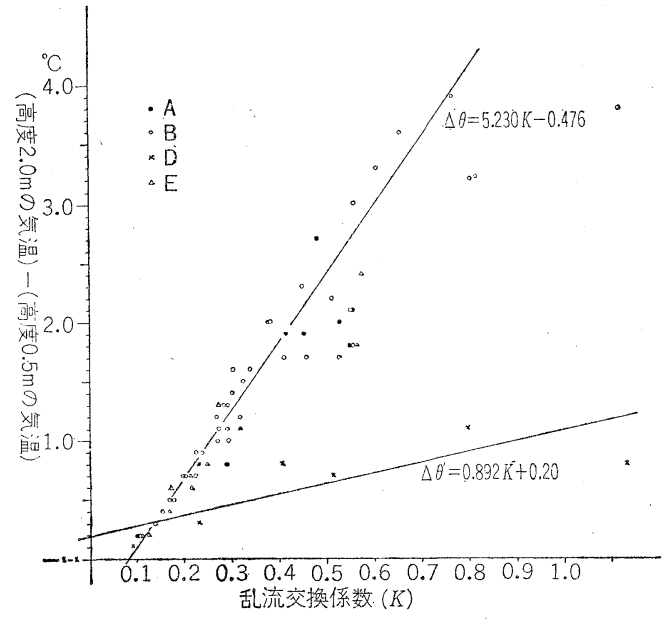

第 8 図乱流交換係数 $(K)$ と(高度 $2 \mathrm{~m}$ の気温 $)$-(高度 $0.5 \mathrm{~m}$ の気 温）の関係

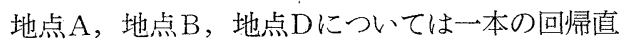
線にのり，回州式は次式で示される.

$$
\Delta \theta=5.230 K-0.476 \mathrm{r}=0.973
$$

ただし， $\Delta \theta$ は $2 \mathrm{~m}$ と $0.5 \mathrm{~m}$ との間の気温差, $K$ は乱流交換係数である.しかし谷底の地点 $\mathrm{E} は$ 他の 3 地点と異った傾向を示し，次式で表わされる.

$$
\Delta \theta_{E}=0.892 K_{E}+0.20 \mathrm{r}=0.838 \cdots \cdots \text { (6) }
$$

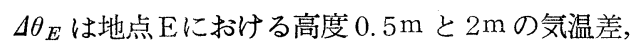

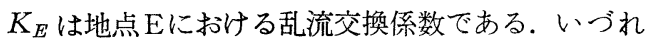
も危険率 0.05 で有意である.

このことは次のように考えられる.この地点 $\mathrm{E} に$ おける風速の垂直構造をくわしく調べた吉野の報 告 ${ }^{3}$ によると, 地点 $\mathrm{E} の$ 風速垂直差 $\Delta u$ が他の地点
と比較して小さい，そのために垂㨁気温差 $\Delta \theta$ が小 さいのにもかかわらずKが大きく変化する.このこ とからも谷底の地点 $\mathrm{E} は$ 他の地点と異った風の性質 を持っているとみなせる。

$$
\text { IV ま と め }
$$

風の乱れにおよぼす小地形の影響について次のこ とがわかった。

（1）風の乱れの強さは，平原上から谷の側壁斜面 を下るにつれて大きくなる。

（2）一般風に対して蔭になる斜面の上部では，一 般風が強くなると，谷の外の気温より高くなる.

(3) 斜面の下部では, 谷の外の乱れの強さが大き くなると谷の外との温度差が大きくなり, 谷底では 谷の外の一般風とは無関係である.

（4）風の蔭になる斜面では，谷の外の乱流交換係 数が大さくなると，それに反比例して小さくなる.

（5）卓越風向に面した斜面では谷の外と比例して 乱流交換係数は変化する.すなわち地上 $1 \mathrm{~m}$ の高度 において，谷の中では谷の外の地点の約 0.7 倍であ る.

(6) $0.5 \mathrm{~m}$ と $2 \mathrm{~m}$ の気温とその地点における乱流 交換係数 $K$ との比例関係からみると, 谷底の地点 $\mathrm{E}$ だけは特性が異なる。

この調査研究を行うにあたり, 資料を提供され, 終始御 指導を賜った現法政大学吉野正敏教授に厚く御礼申し上げ る.また観測は吉野教授の御指導のもとに伊藤久雄, 本間 善吉, 久保田明子, 引田 守の諸兄姉に抢手伝いいただい たことを併せて感謝するものである。

$(1970$ 年 8 月 10 日受理) 